\title{
ANATOMICAL AND BIOCHEMICAL ASPECTS OF THEVETIA PERUVIANA L. A COMMONLY PLANTED ROADSIDE TROPICAL SHRUB OF BHUBANESWAR, ODISHA
}

\author{
JYOTI RANJAN ROUT ${ }^{*}$, ROUT GEORGE KERRYa, LILYPRAVA DASHa, SOUMYA RANJAN NAYAKa, \\ SANTI LATA SAHOO'
}

aDepartment of Biotechnology, Academy of Management and Information Technology, 67/68, IID Centre, Bidya Vihar, Barunei Hills, Khurda 752057, Odisha, India, ${ }^{b}$ Biochemistry and Molecular Biology Laboratory, Post Graduate Department of Botany, Utkal University, Vani Vihar, Bhubaneswar 751004, Odisha, India

Email: routjr@gmail.com

Received: 10 Jan 2017 Revised and Accepted: 09 Mar 2017

\begin{abstract}
Objective: Air pollution is one of the most severe environmental problems of developing cities which adversely affects both plant and human life. However, roadside plants in the urban locations help in reducing the pollution level from the air through foliar surface and act as pollution sink. In this work, an attempt was made to understand the impact of air pollution on urban roadside plants which act as bio indicator.

Methods: A study was conducted to check the impact of urbanization on air pollution by analyzing anatomical and biochemical aspects of Thevetia peruviana L. For anatomical analysis, the transverse sections of leaves were observed under a microscope; whereas for biochemical analysis, the estimation of chlorophyll, carotenoid and protein were determined by spectrophotometric methods. On the other hand, antioxidant enzyme assays, as well as specific activity staining, were performed to study the antioxidant potential. To investigate the antioxidant activity of the leaf extracts, an assay for catalase (CAT), guaiacol peroxidase (GPX) and superoxide dismutase (SOD) were performed. Isoforms of CAT, GPX and SOD were separated using native polyacrylamide gel electrophoresis (PAGE) and their activities were analyzed.
\end{abstract}

Results: Analysis of data revealed that the anatomical disturbances significantly occurred in exposed plants of various sites. Among biochemical parameters, photosynthetic pigments such as chlorophyll a, chlorophyll b, total chlorophyll and carotenoid content were found to be decreased. A maximum $(7.65 \pm 0.51,3.78 \pm 0.56,11.43 \pm 0.91,5.63 \pm 0.55 \mathrm{mg} / \mathrm{g}$, respectively) decrement was noticed in leaves of the Pokhariput plant in comparison to Khorda NH5 $(19.44 \pm 1.08,10.12 \pm 1.03,29.56 \pm 2.32,10.22 \pm 1.21 \mathrm{mg} / \mathrm{g}$, respectively) which is taken as control one. To determine the effect of air pollution on proteins, leaf extracts were analyzed by the Lowry method and sodium dodecyl sulphate-polyacrylamide gel electrophoresis (SDSPAGE). The substantial decrement of total protein and alteration in polypeptides were noticed in polluted sites. Meanwhile, the enhancement of antioxidant enzyme activities such as CAT, GPX and SOD were also detected.

Conclusion: The increment of antioxidant enzymes and alteration of proteins, suggesting the activation of defensive mechanisms in selected plants under air pollution stress and also the plants made physiological and biochemical adjustments to overcome the oxidative damage.

Keywords: Air pollution, Roadside plants, Anatomical aspects, Thevetia peruviana L., Antioxidant enzymes, Photosynthetic pigments, Polypeptides

(C) 2017 The Authors. Published by Innovare Academic Sciences Pvt Ltd. This is an open access article under the CC BY license (http://creativecommons.org/licenses/by/4.0/) DOI: http://dx.doi.org/10.22159/ijpps.2017v9i5.17017

\section{INTRODUCTION}

Earth having an atmosphere is the only planet in the solar systems is responsible for supporting life due to complex and dynamic natural gaseous system. But now the atmosphere of urban areas are under great threat for its air quality as it is mixed up with toxic pollutants like sulfur dioxide $\left(\mathrm{SO}_{2}\right)$, nitrogen oxides $\left(\mathrm{NO}_{\mathrm{x}}\right)$, carbon monoxide (CO), ozone $\left(\mathrm{O}_{3}\right)$, hydrogen fluoride $(\mathrm{HF})$, hydrocarbon, particulate matters and heavy metals $[1,2]$. Air pollution is a major issue in developed and developing cities of India due to rapid industrialization, urbanization, vehicular emissions, energy consumption, economic development and construction activities [1, 3].

Bhubaneswar (the temple city) is the provincial capital of Odisha which is situated in $25^{\circ} 15^{\prime}$ latitude and $85^{\circ} 50^{\prime}$ longitude in the present district of Khurda. It became an important landmark in the history of modern Odisha. According to 2015 smart cities mission, the total population of this city is 840834 ; which was 837737 as per 2011 census. Now the city is categorized into tier-2/smart cities of India as the density (person per square $\mathrm{km}$ ) of the population is 6228 whereas, the density of Odisha is 270 [4-6]. Air pollution in Bhubaneswar is rising in an alarming stage because of various anthropogenic activities. Rapid increase in automobile emissions and building, as well as road constructions, have resulted in most of the air pollution problems for animals and plants $[7,8]$.

Plants are responsible for impingement, absorption and accumulation of various pollutants and thus mitigating the problem. They are directly and constantly exposed to the pollutants and helped to reduce the pollution level from the atmosphere. However, the rate of sensitivity differs from species to species and shows several changes in anatomical and biochemical characteristics $[7,9]$. Mostly, serious damages are occurred in leaves by different toxic pollutants like $\mathrm{SO}_{2}$, $\mathrm{NO}_{\mathrm{x}}$ and $\mathrm{O}_{3}$. Leaves are most susceptible parts of a plant to induce acute injury due to their abundance of stomata, which helps to penetrate the pollutants into the sensitive tissues. Road traffic emissions resulted in changes in foliar anatomy and ultimately caused stomatal occlusion, which led reduction photosynthetic pigments viz., chlorophyll and carotenoids [10]. Moreover, reduction of protein concentration and alteration of peptides is also an indication of ambient air quality which may be achieved due to the inactivation of some enzymes or break down of existing proteins $[11,12]$. Pollutants like $\mathrm{SO}_{2}$, nitrogen dioxide and $\mathrm{O}_{3}$ are mainly responsible to produce vast quantities of reactive oxygen species (ROS) such as hydrogen peroxide $\left(\mathrm{H}_{2} \mathrm{O}_{2}\right)$, nitrite $\left(\mathrm{NO}_{2}{ }^{-}\right)$, hydroxyl $\left(\mathrm{OH} \bullet\right.$, peroxyl $\left(\mathrm{OH}_{2} \bullet\right)$ and superoxide $\left(\mathrm{O}_{2} \bullet-\right)$ radicals to create oxidative stress [13]. But, plants able to overcome the oxidative stress by using antioxidant enzymes such as CAT, GPX and SOD which scavenge different ROS and are considered to be a biomarker for air pollution stress $[14,15]$.

T. peruviana formerly known as Cascabela thevetiais is a medicinal and evergreen dicotyledonous shrub that belongs to family Apocynaceae. It is commonly found in the tropics and sub-tropics and it grows about $10-18$ feet high. There are two varieties of this 
plant, one with yellow flowers and the other with purple flowers [16]. It contains a milky sap containing a compound called thevetin that is used as a heart stimulant, but its natural form is extremely poisonous. The plant has numerous pharmaceutical activities such as antimicrobial, antispermatogenic, anti-inflammatory, piscicidal as well as antifungal properties [17].
This plant is used in roadsides to develop a green belt in Bhubaneswar. However, the morphology is drastically changed during January to May. Therefore considering the above facts, the present work was designed to assess the shocking effects of air pollution on anatomical and biochemical parameters of $T$. peruviana.

Table 1: Changes of $\mathrm{Chl} \mathrm{a,} \mathrm{Chl} b$, total $\mathrm{Chl}$ and carotenoid content in leaf samples of $\mathrm{T}$. peruviana collected from different parts of the Bhubaneswar and Khurda. S1: Rasulgarh; S2: Acharya Vihar; S3: Jayadev Vihar; S4: Baramunda; S5: Pokhariput; S6: Khandagiri; S7: Khorda NH5

\begin{tabular}{llll}
\hline Collected leaf samples & $\begin{array}{l}\text { Chl } \boldsymbol{a} \\
(\mathbf{m g} / \mathbf{g})\end{array}$ & $\begin{array}{l}\text { Chl } \boldsymbol{b} \\
(\mathbf{m g} / \mathbf{g})\end{array}$ & $\begin{array}{l}\text { Total Chl } \\
(\mathbf{m g} / \mathbf{g})\end{array}$ \\
\hline S1 & $16.19 \pm 1.74$ & $7.74 \pm 0.69$ & $23.93 \pm 2.56$ \\
S2 & $17.21 \pm 1.11$ & $8.93 \pm 0.72$ & $26.14 \pm 1.76$ \\
S3 & $15.52 \pm 0.95$ & $8.04 \pm 0.68$ & $23.56 \pm 2.18$ \\
S4 & $12.64 \pm 0.83$ & $6.82 \pm 0.43$ & $19.46 \pm 1.77$ \\
S5 & $7.65 \pm 0.51$ & $3.78 \pm 0.56$ & $11.43 \pm 0.91$ \\
S6 & $8.36 \pm 0.78$ & $5.45 \pm 0.41$ & $13.91 \pm 0.92$ \\
S7 & $19.44 \pm 1.08$ & $10.12 \pm 1.03$ & $7.06 \pm 0.72$ \\
\hline
\end{tabular}

The data represents mean \pm SE of replicates $(n=6)$

\section{MATERIALS AND METHODS}

\section{Chemicals and reagents}

Chemicals and reagents including L-methionine, hydroxylamine hydrochloride, nitro blue tetrazolium (NBT), ethylenediaminetetraacetic acid (EDTA), n-naphthyl ethylenediamine were obtained from Sisco Research Laboratories (Mumbai, India). Sulphanilamide, tritronX-100, riboflavin, $\mathrm{H}_{2} \mathrm{O}_{2}$, guaiacol and tetra-methyl-ethylenediamine (TEMED) were purchased from Himedia Laboratories Pvt. Ltd. (Mumbai, India). The protein molecular weight marker was purchased from Bangalore Genei (Bangalore, India). All other chemicals and solvents were of analytical grade.

\section{Study area and sampling location}

Sampling sites were located in and around the city of Bhubaneswar. Six sampling locations (Rasulgarh, Acharya Vihar, Jayadev Vihar, Baramunda, Pokhariput and Khandagiri) were chosen as the polluted site (named as S1, S2, S3, S4, S5, S6, respectively) while the Khorda was selected as reference site (S7) (fig. 1). The study was carried out from January to May of 2015. The leaf samples were collected and immediately taken to the laboratory for further analysis.

\section{Plant materials}

Thevetia peruviana L. (having yellow flower) was chosen for experimental study as it is widely planted along the divider of roads of Bhubaneswar city (fig. 2). The plant specimen was identified and deposited with voucher number as AMITBTTP20150024. The collected leaf samples were washed and kept in a beaker with water for anatomical analysis whereas, for other tests, samples were washed first and then dried by gentle touching with tissue paper.

\section{Anatomical studies}

With the help of 7 o'clock blade, different transverse sections of leaves were obtained and were kept in petri dish along with water. The fine, selected sections were stained and it would help to distinguish different tissue, cells or inclusions from one another by developing specific colours. The fine thin sections were allowed to immerse in $50 \%$ alcohol for 3-5 min. Then, they were allowed to dip in safranin for $3 \mathrm{~min}$.

The sections were then washed with $50 \%$ alcohol. After washing, they were then placed in $70 \%, 80 \%$ and $90 \%$ alcohol successively for $5 \mathrm{~min}$ each. After that, the sections were placed in fast green for $2 \mathrm{~min}$ and then washed with absolute alcohol. Finally, they were mounted and were observed under a microscope and photographed.

\section{Estimation of chlorophyll and carotenoid}

The chlorophyll extraction and estimation from leaves is done according to the method of Arnon [18]. $0.1 \mathrm{~g}$ of fresh weight was finely cut and ground in cold conditions using $2.0 \mathrm{ml}$ of $80 \%$ acetone in dark. The homogenate was centrifuged for $3 \mathrm{~min}$ at $2800 \mathrm{~g}$. After centrifugation, the supernatant was collected and the procedure was repeated up to $10 \mathrm{ml}$ of the collection with $80 \%$ acetone. The optical density (OD) of the supernatant was determined by spectrophotometrically at different wavelengths like $480 \mathrm{~nm}, 649 \mathrm{~nm}$ and $665 \mathrm{~nm}$ for chlorophyll a, chlorophyll b and total chlorophyll, respectively.

But for carotenoid, the absorbance was taken at $480 \mathrm{~nm}$ and 510 $\mathrm{nm}$. The chlorophyll content was measured according to Strain et al. [19], whereas the carotenoid contents were calculated as per the method of Duxbury and Yentsch [20]. The results were expressed as mg/g of fresh weight of plant sample.

\section{Extraction and estimation of protein}

Collected leaf samples (3: 1; buffer volume: fresh weight) were homogenized in pre-chilled mortar and pestle with $50 \mathrm{mmol}$ potassium phosphate buffer ( $\mathrm{pH} 7.8$ ), $50 \mathrm{mmol}$ EDTA, $2 \mathrm{mmol}$ phenyl methyl sulfonyl fluoride (PMSF) and $10 \%(\mathrm{w} / \mathrm{v})$ insoluble polyvinylpyrrolidone (PVP) to fine slurry followed by centrifugation at $14000 \mathrm{~g}$ for $15 \mathrm{~min}$ at $4{ }^{\circ} \mathrm{C}$. The supernatants were taken for protein estimation, SDS-PAGE analysis and antioxidant enzyme (CAT, GPX and SOD) activities. The concentration of protein was done according to the method of Lowry et al. [21] using bovine serum albumin as a standard.

\section{Analysis of protein profile by SDS-PAGE}

The supernatant containing equal amounts $(50 \mu \mathrm{g})$ of proteins were separated on $5 \%$ stacking and $10 \%$ resolving polyacrylamide slab gels at a constant current of $35 \mathrm{~mA}$ for $4 \mathrm{~h}$ [22]. Separated polypeptides on the gel were visualized by the silver staining method [23].

The gels were then scanned and photographed by gel documentation system and analyzed with the quantity one software from Bio-Rad (Bio-Rad, Italy). In order to achieve the precise sizing of the separated polypeptides, a protein molecular weight marker [phosphorylase b $(97.4 \mathrm{kDa})$; bovine serum albumin (66.0 kDa); ovalbumin (43.0 kDa); carbonic anhydrase (29.0 kDa); lactoglobulin (18.4 kDa)] was used as a standard. 


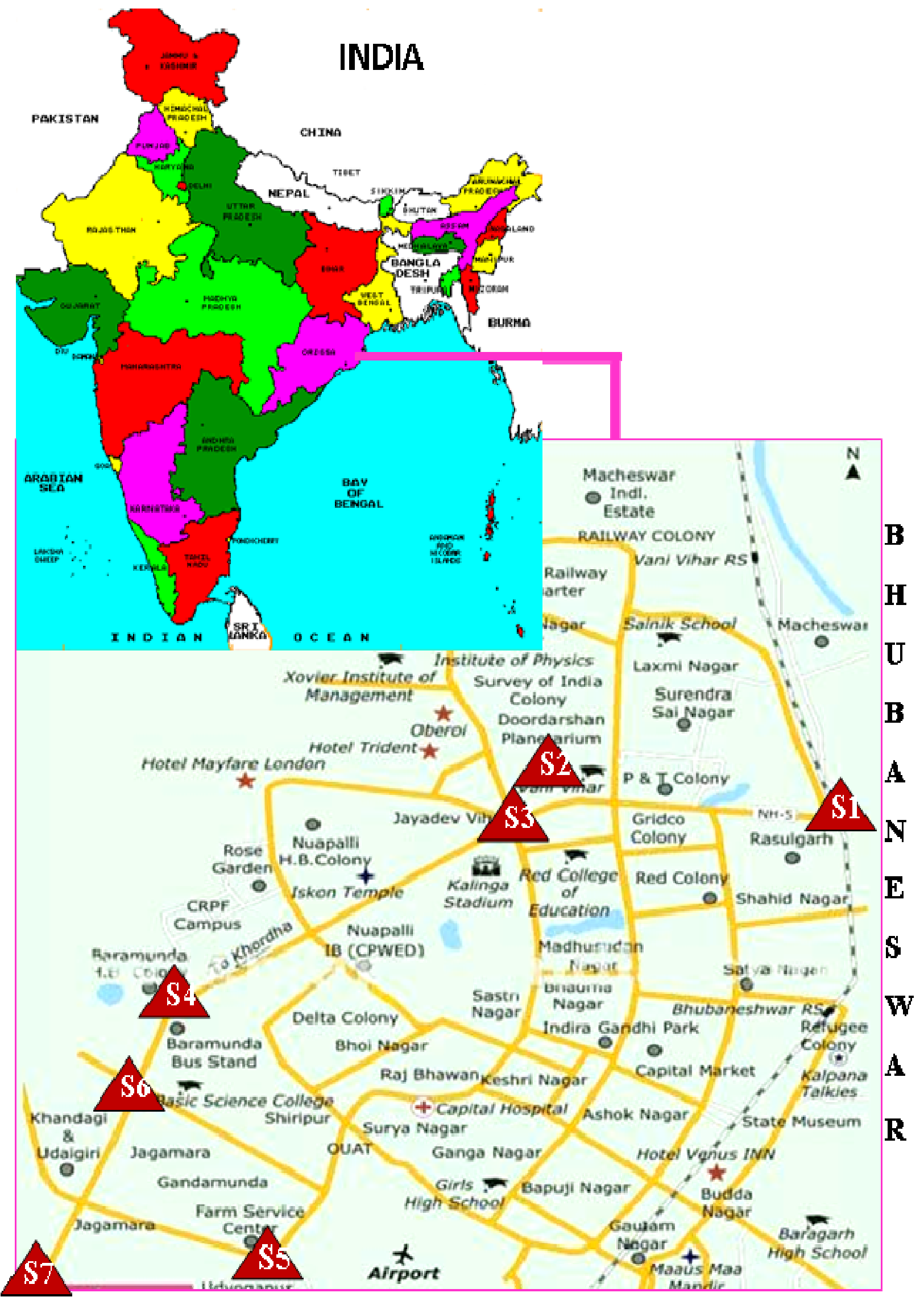

Fig. 1: Location of sample collecting sites from Bhubaneswar and Khurda. 

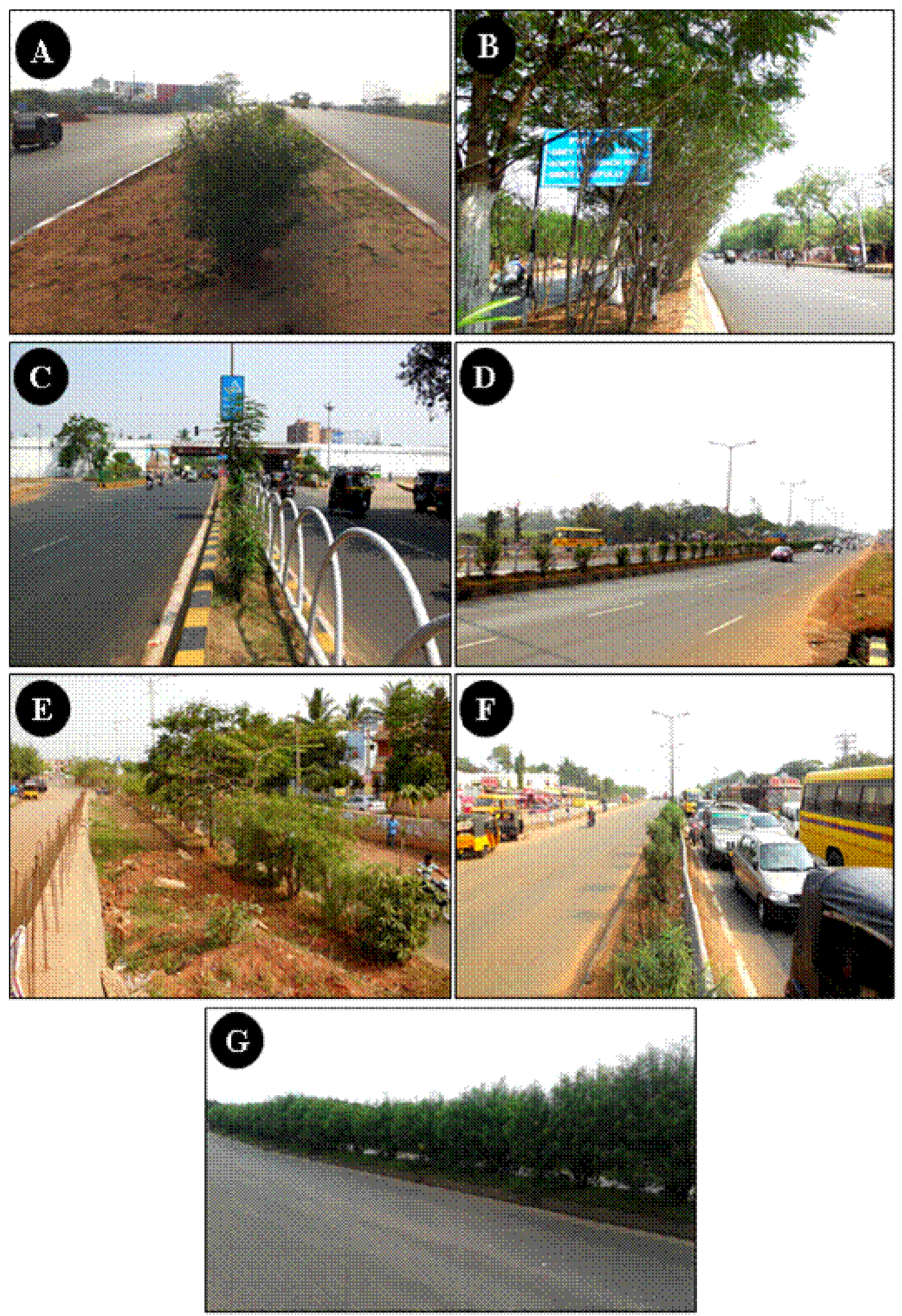

Fig. 2: Collection sites of T. peruviana from different parts of the Bhubaneswar and Khurda. A: Rasulgarh; B: Acharya Vihar; C: Jayadev Vihar; D: Baramunda; E: Pokhariput; F: Khandagiri; G: Khorda NH5. 

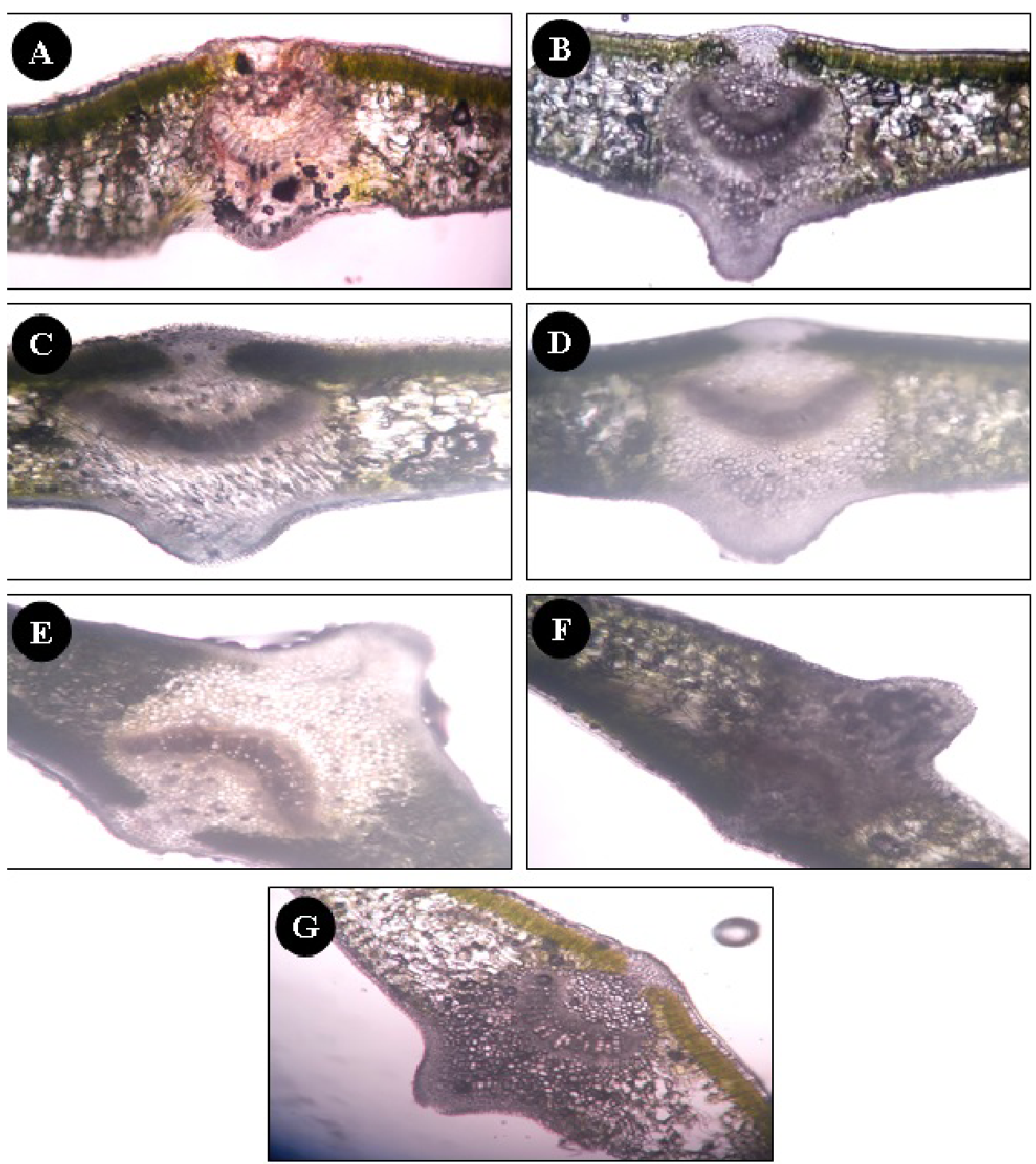

Fig. 3: Transverse section of leaf samples T. peruviana collected from different parts of the Bhubaneswar and Khurda. A: Rasulgarh; B: Acharya Vihar; C: Jayadev Vihar; D: Baramunda; E: Pokhariput; F: Khandagiri; G: Khorda NH5.

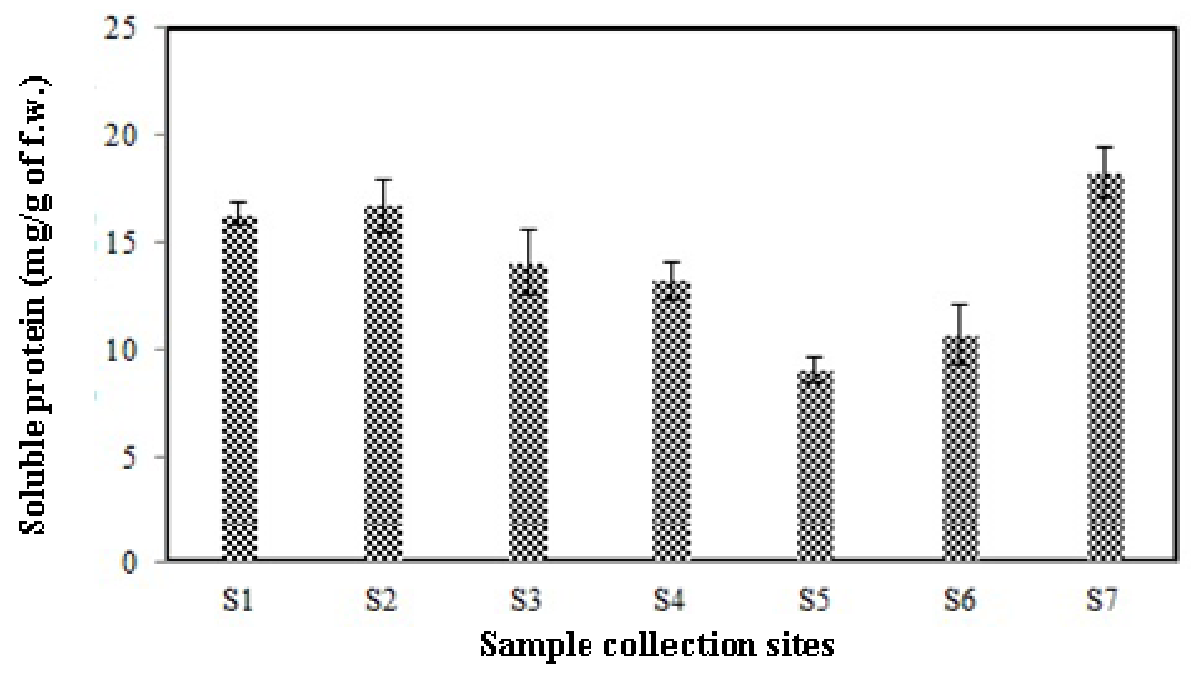

Fig. 4: Soluble protein estimation from leaves of T. peruviana, collected from different parts of the Bhubaneswar and Khurda. S1: Rasulgarh; S2: Acharya Vihar; S3: Jayadev Vihar; S4: Baramunda; S5: Pokhariput; S6: Khandagiri; S7: Khorda NH5. The data represents mean \pm SE of replicates $(n=6)$ 


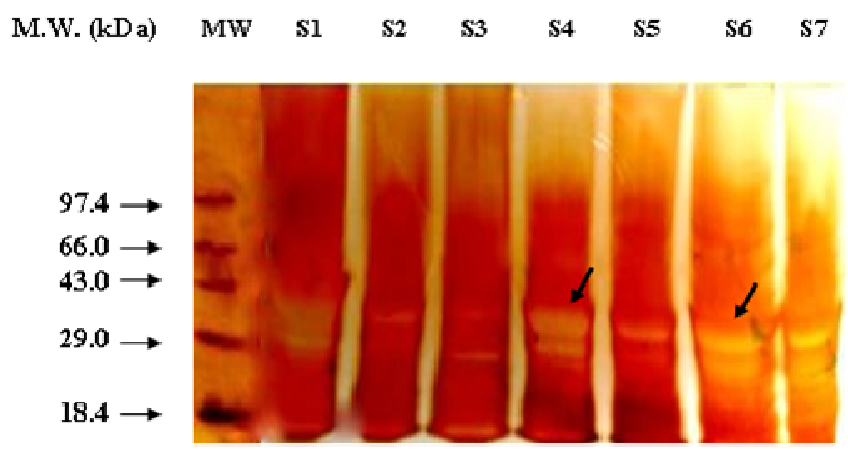

Fig. 5: SDS-PAGE profiling of leaf samples of Thevetia peruviana L. collected from different parts of the Bhubaneswar and Khurda. MW: molecular weight (MW) of protein standards are indicated; S1: Rasulgarh; S2: Acharya Vihar; S3: Jayadev Vihar; S4: Baramunda; S5: Pokhariput; S6: Khandagiri; S7: Khorda NH5.
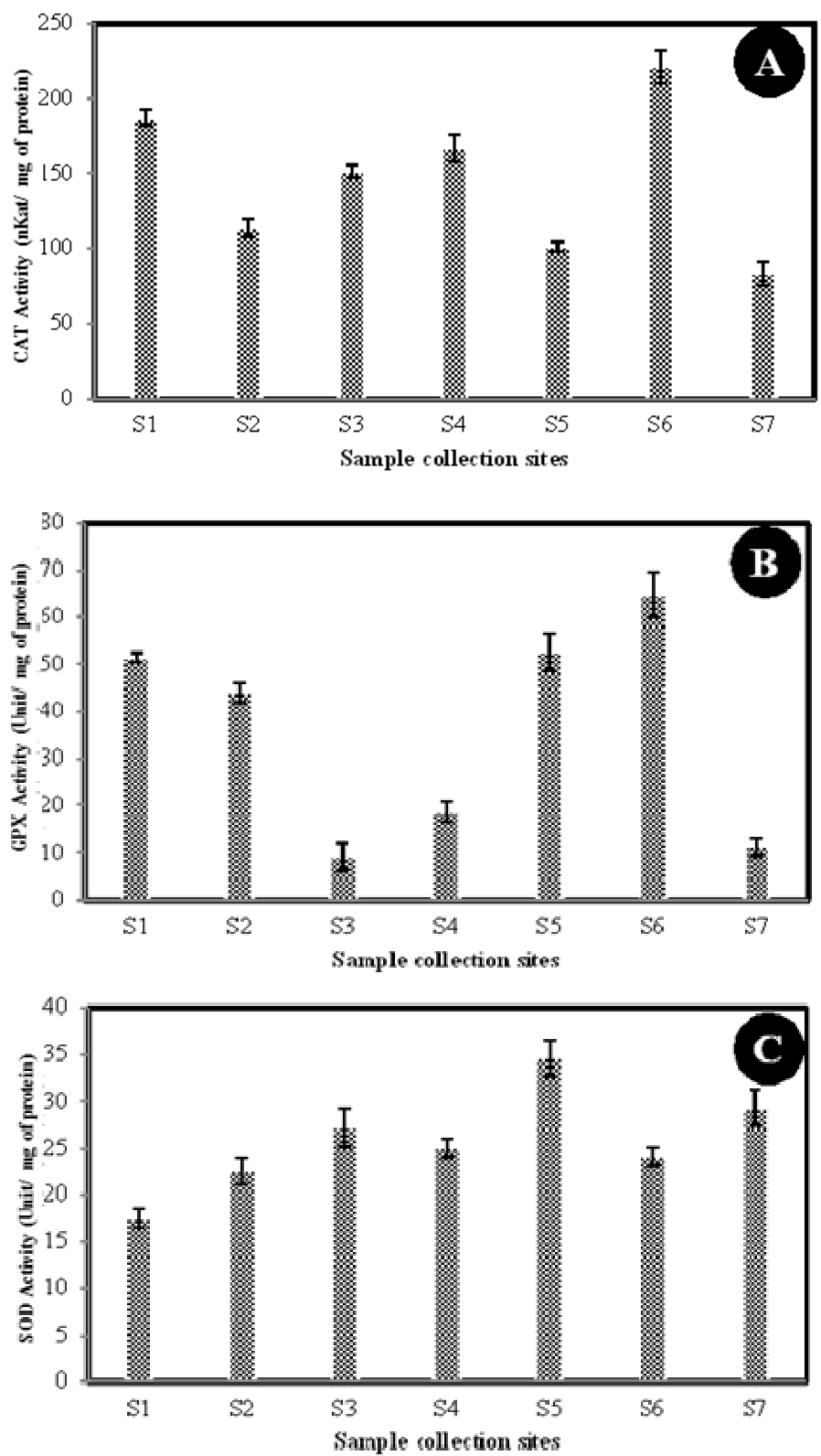

Fig. 6: Changes in the specific activities of CAT (A), GPX (B) and SOD (C) from leaf samples of Thevetia peruviana L. collected from different parts of the Bhubaneswar and Khurda. S1: Rasulgarh; S2: Acharya Vihar; S3: Jayadev Vihar; S4: Baramunda; S5: Pokhariput; S6:

Khandagiri; S7: Khorda NH5. The data represents mean \pm SE of replicates $(n=6)$ 


\section{$\begin{array}{lllllll}\mathrm{S1} & \mathrm{S} 2 & \mathrm{~S} 3 & \mathrm{~S} 4 & \mathrm{~S} 5 & \mathrm{~S} 6 & \mathrm{~S} 7\end{array}$}

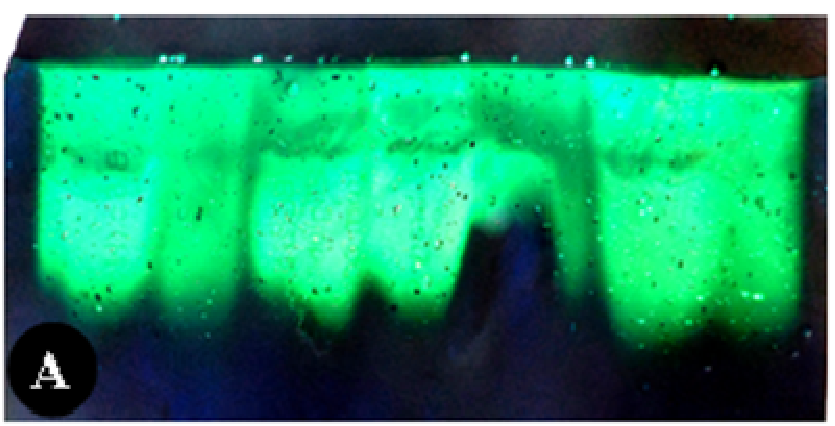

CAT-I
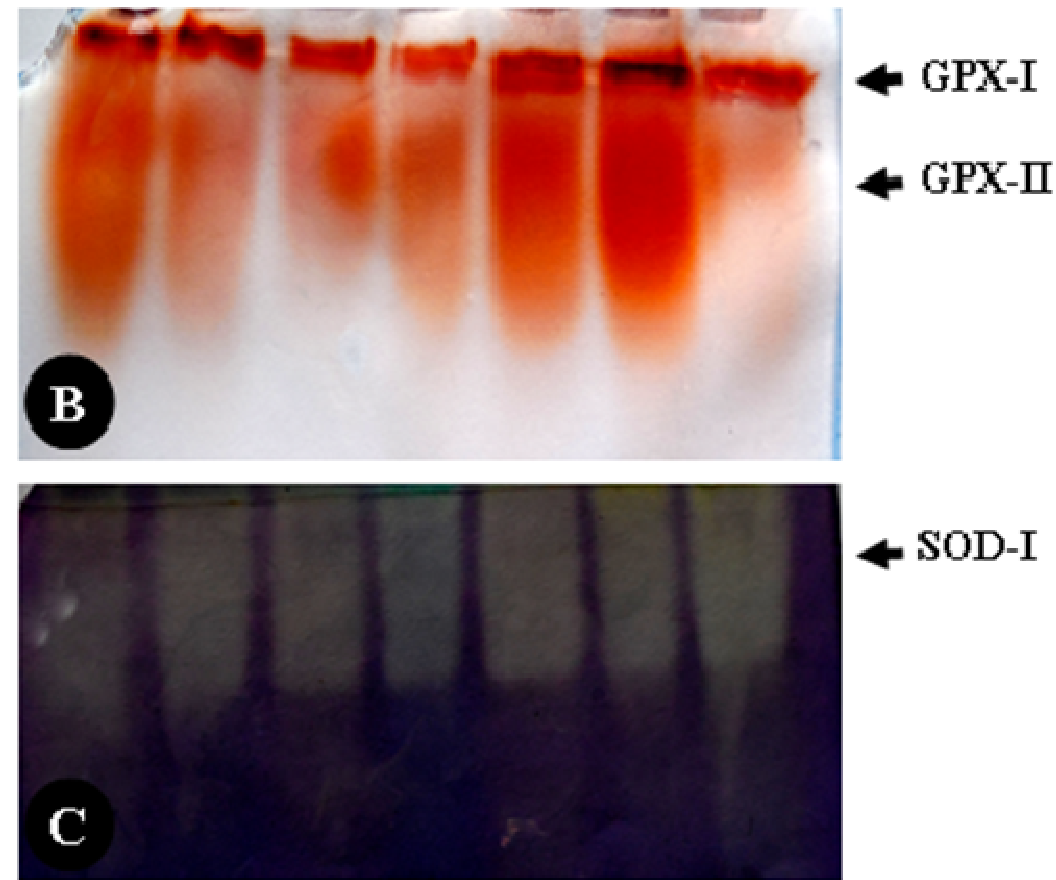

Fig. 7: Activity staining for CAT (A), GPX (B) and SOD (C) from leaf samples of Thevetia peruviana L. collected from different parts of the Bhubaneswar and Khurda. Lane S1: Rasulgarh; Lane S2: Acharya Vihar; Lane S3: Jayadev Vihar; Lane S4: Baramunda; Lane S5: Pokhariput; Lane S6: Khandagiri; Lane S7: Khorda NH5.

\section{Antioxidant enzyme assay}

CAT activity was determined by measuring the decrease in $\mathrm{H}_{2} \mathrm{O}_{2}$ concentration at $240 \mathrm{~nm}$ and the activity was calculated by using the molar extinction coefficient of $\mathrm{H}_{2} \mathrm{O}_{2}(40.0 \mathrm{mmol} / \mathrm{cm})$ [24]. Enzymatic activity was determined at $25^{\circ} \mathrm{C}$ using $0.5 \mathrm{ml}$ of enzyme extract ( 50 $\mu \mathrm{g}$ of protein), $2.0 \mathrm{ml}$ of $100 \mathrm{mmol}$ potassium phosphate buffer $(\mathrm{pH}$ 6.8 ) and $0.5 \mathrm{ml}$ of $10 \mathrm{mmol} \mathrm{H}_{2} \mathrm{O}_{2}$. The specific activity was expressed as nKat per mg of protein. GPX activity was assayed as described by Bergmeyer [25]. The assay was done by taking a reaction mixture consisting of $2.8 \mathrm{ml}$ of $100 \mathrm{mmol}$ potassium phosphate buffer $(\mathrm{pH}$ 7.0), $0.05 \mathrm{ml}$ of $0.018 \mathrm{M}$ guaiacol and $0.05 \mathrm{ml}$ of $10 \mathrm{mmol} \mathrm{H}_{2} \mathrm{O}_{2}$. The reaction was started by the addition of enzyme extract $(0.1 \mathrm{ml})$ equivalent to $50 \mu \mathrm{g}$ protein. The change in absorbance at $436 \mathrm{~nm}$ due to the oxidation of guaiacol to form tetra guaiacol in the presence of $\mathrm{H}_{2} \mathrm{O}_{2}$ was measured and expressed in units per mg of protein. SOD activity was assayed by measuring the inhibition of $\mathrm{O}_{2} \bullet$-driven $\mathrm{NO}_{2}$-formation from hydroxylamine hydrochloride according to Das et al. [26]. The reaction mixture was prepared by mixing $1.110 \mathrm{ml}$ of $50 \mathrm{mmol}$ phosphate buffer ( $\mathrm{pH} 7.8$ ), $0.075 \mathrm{ml}$ of $20 \mathrm{mmol}$ L-methionine, $0.040 \mathrm{ml}$ of $1 \%(\mathrm{v} / \mathrm{v})$ triton X-100, $0.075 \mathrm{ml}$ of $10 \mathrm{mmol}$ hydroxylamine hydrochloride and $0.1 \mathrm{ml}$ of $50 \mu \mathrm{M}$ EDTA. To this mixture, $0.1 \mathrm{ml}$ of enzyme extract ( $50 \mu \mathrm{g}$ protein) and $0.08 \mathrm{ml}$ of riboflavin $(50 \mu \mathrm{M})$ were added. The reaction was started by exposing the mixture to cool white fluorescent light for $10 \mathrm{~min}$. After this period the light was switched off, $1 \mathrm{ml}$ of greiss reagent (prepared freshly by mixing an equal volume of $1 \%$ sulphanilamide in $5 \%$ phosphoric acid and $0.1 \% \mathrm{~N}$-1-napthyl ethylene diamine) was added to each tube and the absorbance was measured at 543 $\mathrm{nm}$. One unit of enzyme activity is defined as the amount of SOD capable of inhibiting $50 \%$ of $\mathrm{NO}_{2}$-formation. The enzyme activity was calculated from the value of $V_{0} / \mathrm{V}-1$, where $\mathrm{V}_{0}$ is the absorbance of the control (without enzyme) and $V$ is the absorbance of the sample. The activity was expressed as units per mg of protein.

\section{Enzyme activity staining}

CAT activity in non-denaturing PAGE was done as described by Woodbury et al. [27]. CAT isoenzymes were visualized by incubating the gels in $0.003 \% \mathrm{H}_{2} \mathrm{O}_{2}$ for $10 \mathrm{~min}$ at room temperature $\left(25^{\circ} \mathrm{C}\right)$. The gels were then rinsed with distilled water and finally stained in a reaction mixture containing $2 \%(\mathrm{w} / \mathrm{v})$ potassium ferricyanide and $2 \%(\mathrm{w} / \mathrm{v})$ ferric chloride for $10 \mathrm{~min}$. Activity staining of GPX was performed on $10 \%$ PAGE according to staining procedure of Hamill and Brewbaker [28]. The gels were washed with distilled water and immersed for $30 \mathrm{~min}$ at room temperature in $0.018 \mathrm{M}$ guaiacol, rinsed twice with deionized water, and then immersed in a solution of $0.015 \% \mathrm{H}_{2} \mathrm{O}_{2}$ in $1 \%$ acetic acid. SOD was localized by using a photochemical method of Beauchamp and Fridovich [29]. The gels incubated in staining buffer $[50 \mathrm{mmol}$ potassium phosphate buffer 
(pH 7.8), $0.1 \mathrm{mmol}$ EDTA, $28 \mathrm{mmol}$ TEMED, $0.003 \mathrm{mmol}$ riboflavin and $0.25 \mathrm{mmol}$ NBT] for $30 \mathrm{~min}$ in the dark at room temperature. The gels were then placed on a clean glass plate and illuminated by two fluorescent tubes $(20 \mathrm{~W}$ each) until the SOD activity bands became visible.

\section{Statistical analysis}

All results are the mean of three independent experimental replicates $(\mathrm{n}=6)$ and data is reported as mean \pm standard error.

\section{RESULTS AND DISCUSSION}

\section{Anatomical characteristics}

The present studies on the T. peruviana growing in all parts of Bhubaneswar indicate an adverse effect on the micromorphological structure. In the present investigation, it has been observed that the stomatal and epidermal structures changed which indicates the rate of pollutants is different in important areas of Bhubaneswar. The data was compared with the reference plants grown in NH5 of Khurda (S7) which is $22 \mathrm{KM}$ way from Bhubaneswar. The size of epidermal cells and stomata normally accompanied by an increase in the size of epidermal cells as shown in fig. 3. Almost all plants growing in different parts of the city (Rasulgarh, Acharya Vihar, Jayadev Vihar, Baramunda, Pokhariput and Khandagiri) disturbed its anatomical appearance as compared to the leaves of outside city (Khorda NH5). Our results were in conformity with the findings of Mishra [30] which was studied the effect of environmental pollution on leaf anatomy of Commelina bengalensis. Reduction of leaf mesophyll, palisade parenchyma and upper and lower epidermis in Tanacetum vulgare was also observed by Stevovi et al. [31]. Stomatal abnormality (clogging and reduction of size) and reduction of the epidermis are occurred due to high deposition of dust particles or increased concentrations of toxic gasses such as $\mathrm{CO}_{2}$ and $\mathrm{SO}_{2}$, which is a symptom of air pollution [32].

\section{Chlorophyll and carotenoid content}

The data collected for six polluted sites (S1, S2, S3, S4, S5 and S6) of Bhubaneswar city were compared with reference site (S7) to find out the impact of air pollution on the plant. The photosynthetic pigments are said to be an index of plant productivity, hence any alteration in concentration may change the morphological, physiological, and biochemical behavior of the plant. From the analysis of the results of chlorophyll and carotenoid pigments, a considerable reduction was found at all the polluted sites (S1, S2, S3, S4, S5 and S6) compared to the control site (S7) during the entire study period. The obtained results (table 1 ) have shown the negative impact of automobile emissions and dust particles on chlorophyll as well as the carotenoid content of $T$. peruviana. At Site 5 (Pokhariput), a significant decrement was observed in chlorophyll content as compared to Site 7 (Control site; Khorda NH5). Among all experimental sites, the maximum decrement was noticed in S5 plants then followed by S6, S4, S3, S1, S2.

A similar pattern of decrement was observed in carotenoid content from leaves of T. peruviana collected from different polluted sites of Bhubaneswar and was compared with plants that are growing outside from Bhubaneswar town (nearby $\mathrm{NH}$ of Khurada). This is probably due to the exchange of gaseous $\mathrm{SO}_{2}$ which causes direct injury to plants by entering the leaves through the stomata [33] and dry or wet deposition of dust on the leaves causing reduced interception of incident light and clogging of stomata [34]. Significant reduction in chlorophyll and carotenoid content at the air polluted area were also recorded on ornamental and vegetable plants, respectively $[1,2]$.

\section{Protein content and SDS-PAGE analysis}

The total soluble protein content was found to be maximum $(18.27 \pm 1.23 \mathrm{mg} / \mathrm{g}$ of $\mathrm{f}$. w.) in S7, which was 2 -folds higher than leaf samples of $55(9.03 \pm 0.52 \mathrm{mg} / \mathrm{g}$ of $\mathrm{f}$. w.) plants. No significant changes were observed in between S1 and S2 plants $(16.32 \pm 0.61$ and $16.68 \pm 1.03 \mathrm{mg} / \mathrm{g}$ of $\mathrm{f}$. w., respectively). Among all sampling sites, the maximum decreased concentrations of protein were obtained from S5 and S6 samples (fig. 4). When analyzed in SDSPAGE, the total number of protein bands was found to be different in
S4 and S6 plants where it was expressing more in comparison to others. However, some polypeptides were disappeared in S2 and S3 plants as shown in fig. 5. Plant protein is an essential biochemical component for the plant growth which is significantly reduced from the leaves of T. peruviana collected from high polluted areas (S1, S2, S3, S4, S5 and S6) as compared to reference area (S7). The reduction of protein content is an indication of pollutants load which is concluded by Rai and Panda [12] by testing twelve plant species from road-side. The decrease in protein concentration also may be due to the inactivation of some enzymes or break down of existing protein to amino acid through air pollutants such as either through toxic gases or accumulation of heavy metals [2, 12]. The disappearance of some proteins and the de novo synthesis of others were resulted from SDS-PAGE analysis, which indicates the impact of air pollution on plants. Similar experiments also conducted by several workers to evaluate the major changes of protein in different plant species exposed to air pollution $[11,35,36]$.

\section{Antioxidant enzyme activities}

The results of experiment exhibited that the planted T. peruviana when exposed to various polluted areas of Bhubaneswar city showed changes in antioxidant enzymes. According to the results (fig. 6A), the maximum activity $(221.28 \pm 19.22 \mathrm{nKat} / \mathrm{mg}$ of protein) of CAT of leaves was recorded at site $\mathrm{S} 6$ whereas, the minimum activity $(83.49 \pm 7.07 \mathrm{nKat} / \mathrm{mg}$ of protein) was observed at site S7. According to the changes in the activity of the CAT enzyme, sites are arranged in the following patterns: $\mathrm{S} 6>\mathrm{S} 1>\mathrm{S} 4>\mathrm{S} 3>\mathrm{S} 2>\mathrm{S} 5>\mathrm{S} 7$. While analyzing the CAT activity in non-denaturing PAGE, a single isoform (CAT-I) is appeared in leaf samples of all experimental sites however, the intensity of bands are altered.

The maximum intensities were observed in leaves of S6 and S1 sites plants (Shown in fig. 7A). The changes in GPX activity was also recorded from different sites of the study area, which are illustrated in fig. 6B. The maximum activity was noticed in S6 (64.68 \pm 6.12 Unit/mg of protein) which was near about 6 times higher than reference site $\mathrm{S} 7$ (11.23 $\pm 0.94 \mathrm{Unit} / \mathrm{mg}$ of protein). But the maximum decrement was found in S3 $(9.12 \pm 1.52 \mathrm{Unit} / \mathrm{mg}$ of protein). There are two isoforms (GPX-I and GPX-II) appeared in all sites of Bhubaneswar and Khurda.

However, the lowest intensity was observed in leaves of Khurda plants (fig. 7B). No such significant results were noticed in the case of SOD activity (either assay or activity staining) in leaf samples of all collected sites.

The activity was higher in polluted site S5 $(34.62 \pm 3.41 \mathrm{Unit} / \mathrm{mg}$ of protein) as compared to reference one $(29.33 \pm 1.68 \mathrm{Unit} / \mathrm{mg}$ of protein) which indicates as a non-significant (Shown in fig. 6C). The isoenzyme patterns of SOD was studied through native PAGE and found that only one band (SOD-I) was obtained in leaf samples of all sites but the minimum intensity was appeared in S1 and is shown in fig. 7C. Environmental pollutants such as heavy metals, dust and gases are not only responsible to disturb the plant growth and development but also produce more ROS. However, antioxidative enzymes like CAT, GPX and SOD are playing a vital function in the cells to prevent the build-up of ROS [15, 37, 38]. Increased activities of these enzymes are considered as indicators of oxidative stress in plants. Among antioxidant enzymes, peroxidase activity in plants was found to be a sensitive indicator of $\mathrm{SO}_{2}$ and $\mathrm{NO}_{2}$ which is a suggested biomarker to evaluate urban air pollution [9].

\section{CONCLUSION}

On the basis of this study, it is concluded that the air pollutants especially roadside dust and automobile exhaust have a great deterioration effect on the stability level of the leaves of the $T$. peruviana $\mathrm{L}$. in terms of the fluctuating anatomical appearance. The reduction of photosynthetic pigments is also an indication of heavy phytotoxic air pollutant loads in Bhubaneswar city. The study results that there is an alteration of proteins and enhanced activities of antioxidant enzymes to overcome the oxidative damage caused by various pollutants which is an indication of rapid urbanization and threatening towards human health problem. 


\section{ACKNOWLEDGEMENT}

The authors like to thank the Chairman, Academy of Management and Information Technology for giving permission to do the laboratory work and to Mrs. Smruti Rout for correcting the English error of the manuscript.

\section{AUTHOR CONTRIBUTION}

Jyoti Ranjan Rout has interpreted data, wrote the manuscript and acted as the corresponding author. Rout George Kerry and Lilyprava Dash have devoted their time in analyzing the result of the study. Soumya Ranjan Nayak has performed analysis of all samples whereas, Santi Lata Sahoo helped to evaluate and edit the manuscript.

\section{CONFLICT OF INTERESTS}

The authors declare that they have no conflict of interest.

\section{REFERENCES}

1. Shiragave PD, Ramteke AA, Patil SD. Plant responses to vehicular pollution: specific effect on photosynthetic pigments of plants at divider of NH-4 highway Nipani area Karnataka state India. Cent Eur J Exp Biol 2015;4:16-9.

2. Skinder BM, Sheikh AQ, Pandit AK, Ganai BA, Kuchy AH. Effect of brick kiln emissions on commonly used vegetables of Kashmir valley. Food Sci Nutr 2015;3:604-11.

3. Deepalakshmi AP, Ramakrishnaiah H, Ramachandra YL, Radhika RN. Roadside plants as bioindicators of urban air pollution. IOSR J Environ Sci Toxicol Food Technol 2013;3:10-4.

4. Anonymous. Orissa population census; 2011. http://www. census2011.co.in/census/state/orissa.html. [Last accessed on 05 Dec 2016]

5. Sabat AK. Analysis of the underlying causes of environmental degradation in Bhubaneswar city. Int J Eng Res Appl 2012;2:210-4.

6. Anonymous. Smart cities mission. Ministry of urban development, Government of India; 2015. http://smartcities. gov.in/writereaddata/CitiesProfile/Orissa_Bhubaneswar.pdf. [Last accessed on 05 Dec 2016]

7. Pawar K, Dube B, Maheshwari R, Bafna A. Biochemical aspects of air pollution induced injury symptoms of some common ornamental roadside plants. Int J Biol Med Res 2010;1:291-4.

8. Mohapatra K, Biswal SK. Assessment of ambient air quality index (AQI) in Bhubaneswar, the capital city of Odisha. Int J Adv Res Sci Eng 2014;3:190-6.

9. Verma V, Chandra N. Biochemical and ultrastructural changes in Sida cordifolia L. and Catharanthus roseus L. to auto pollution. Int Scholarly Res Not 2014;2014:1-11.

10. Williams RJH, Lloyd MM, Ricks GR. Effects of atmospheric pollution on deciduous woodland I: Some effects on leaves of Quercus petraea (Mattuschka) Leibl. Environ Pollut 1971;2:57-68.

11. Govindaraju M, Ganeshkumar RS, Suganthi P, Muthukumaran VR, Visvanathan P. Impact assessment of air pollution stress on plant species through biochemical estimations. World Acad Sci Eng Technol 2010;4:696-9.

12. Rai PK, Panda LLS. Roadside plants as bioindicators of air pollution in an industrial region, Rourkela, India. Int J Adv Sci Technol 2015;4:14-36.

13. Rai R, Rajput M, Agrawal M, Agrawal SB. Gaseous air pollutants: a review on current and future trends of emissions and impact on agriculture. J Sci Res 2011;55:77-102.

14. Seyyednejad SM, Koochak H, Vaezi J. Changes in anti-oxidative enzymes activity, protein content and ascorbic acid level in Prosopis juliflora exposed to industrial air pollution. J Biol Today's World 2013;2:482-92.

15. Patykowski J, Kołodziejek J. Changes in antioxidant enzyme activities of european mistletoe (Viscum album L. Subsp. Album) leaves as a response to environmental stress caused by pollution of the atmosphere by nitrogen dioxide. Pol J Environ Stud 2016:25:725-32.

16. Usman L, Oluwaniyi O, Ibiyemi S, Muhammad N, Ameen O. The potential of oleander (Thevetia peruviana) in African agricultural and industrial development: a case study of Nigeria. J Appl Biosci 2009;24:1477-87.

17. Rajbhar N, Kumar A. Pharmacological importance of Thevetia peruviana. Int J Pharm Chem Sci 2014;3:260-3.

18. Arnon DI. Copper enzymes in isolated chloroplasts: polyphenol oxidases in Beta vulgaris. Plant Physiol 1949;24:1-15.

19. Strain HN, Bengavin TC, Walter AS. Analytical procedure for isolation, identification, estimation and investigation of chlorophyll. In: Pietro AS. Methods in enzymology. Academic Press: New York: NY; 1971. p. 452-76.

20. Duxbury AC, Yentsch CS. Plankton pigment monographs. J Mar Res 1956;15:19-101.

21. Lowry $\mathrm{OH}$, Rosebrough NJ, Farr AL, Randall RJ. Protein measurement with the folin phenol reagent. J Biol Chem 1951;193:265-75.

22. Laemmli UK. Cleavage of structural proteins during the assembly of the head of bacteriophage T4. Nature 1970;227:680-5.

23. Switzer RC. A highly sensitive silver stain for detecting proteins and peptides in polyacrylamide gels. Anal Biochem 1979;98:231-7.

24. Aebi HE. Catalase. In: Bergmeyer H. Method of Enzymatic analysis. Chemie: Weinheim: Germany; 1983. p. 273-7.

25. Bergmeyer HU. Methods of enzymatic analysis. $2^{\text {nd }} \mathrm{Ed}$. Academic Press: New Work; 1974.

26. Das K, Samanta L, Chainy GBN. A modified spectrophotometric assay of superoxide dismutase using nitrite formation by superoxide radicals. Indian J Biochem Biophys 2000;37:201-4.

27. Woodbury W, Spencer A, Stahman M. An improved procedure using ferricyanide for detecting catalase isozymes. Anal Biochem 1971;44:301-5.

28. Hamill DE, Brewbaker JL. Isoenzyme polymorphism in flowering plants. IV. The peroxidase isoenzymes of maize (Zea mays L.). Physiol Plant 1969;22:945-58.

29. Beauchamp C, Fridovich I. Superoxide dismutase: Improved assay applicable to acrylamide gels. Anal Biochem 1971;44:276-87.

30. Mishra LC. Effect of environmental pollution on the morphology and leaf epidermis of Commelina bengalensis Linn. Environm Pollut 1982;28:281-4.

31. Stevovi S, Mikovilovi VS, Dragosavac DC. Environmental impact on morphological and anatomical structure of Tansy. Afr J Biotechnol 2010;9:2413-21.

32. Raina AK, Bala C. Effect of vehicular pollution on Duranta repens L. in Jammu city. J Appl Nat Sci 2011;3:211-8.

33. Heather G. Effect of air pollution on agricultural crops. Ministry of Agriculture, ON, Canada; 2003.

34. Chauhan A, Joshi PC. Effect of ambient air pollutants on wheat and mustard crops growing in the vicinity of urban and industrial areas. N Y Sci J 2010;3:52-60.

35. Rezanejad F. Air pollution effects on structure, proteins and flavonoids in pollen grains of Thuja orientalis L. (Cupressaceae). Grana 2009;48:205-13.

36. Rezanejad F, Majd A, Shariatzadeh SMA, Moein M, Aminzadeh M, Mirzaeian M. Effect of air pollution on soluble proteins, structure and cellular material release in pollen of Lagerstroemia indica $\mathrm{L}$. (Lytraceae). Acta Biol Cracov Ser Bot 2003;45:129-32.

37. Rout JR, Sahoo SL, Das R, Ram SS, Chakraborty A, Sudarshan M. Changes in antioxidant enzyme activities and elemental profiling of Abutilon indicum L. subjected to copper stress. Proc Natl Acad Sci India-Sect B Biol Sci 2016. Doi:10.1007/s40011016-0725-z

38. Jana K, Ghosh A, Ghosh D. In vitro antioxidant potentiality of ethyl acetate fraction of the seed of Eugenia jambolana. Asian J Pharm Clin Res 2015;8:167-70.

\section{How to cite this article}

- Jyoti Ranjan Rout, Rout George Kerry, Lilyprava Dash, Soumya Ranjan Nayak, Santi Lata Sahoo. Anatomical and biochemical aspects of Thevetia peruviana L.: a commonly planted roadside tropical shrub of bhubaneswar, odisha. Int J Pharm Pharm Sci 2017;9(5):51-59. 